\title{
Kesan Penambahan Kappaphycus alvarezii, Gelatin Ikan dan Gelatin Kaki Ayam terhadap Ciri-ciri Kualiti Sosej Ayam
}

(The Addition of Kappaphycus alvarezii, Fish and Chicken Feet Gelatins Effects on the Properties of Chicken Sausages)

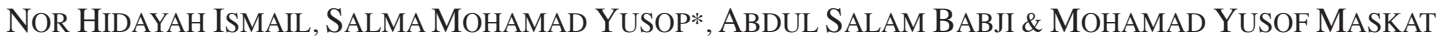

\begin{abstract}
ABSTRAK
Kappaphycus alvarezii kaya dengan karagenan yang banyak digunakan dalam industri makanan sebagai agen pemekat dan penstabil. Penggunaan gelatin ikan dan ayam dalam produk makanan dapat menggantikan gelatin lembu yang mempunyai banyak isu terutamanya berkaitan halal dan penyakit lembu gila (BSE). Penyelidikan ini adalah untuk menentukan kesan penambahan Kappaphycus alvarezii, gelatin ikan dan gelatin kaki ayam terhadap ciri-ciri kualiti sosej ayam. Dua formulasi optimum $T 1$ (10\% Kappaphycus alvarezii, 3.81\% gelatin ikan, 7.63\% gelatin kaki ayam) dan T2 (2.57\% Kappaphycus alvarezii, 5\% gelatin ikan, 7.63\% gelatin kaki ayam) telah diperoleh daripada Kaedah Respon Permukaan (RSM) dalam kajian awalan. Kualiti sosej ayam dikaji berdasarkan analisis proksimat dan ujian jangka hayat ( $\mathrm{pH}$, nilai TBA dan warna). Ujian jangka hayat dijalankan selama 3 minggu pada suhu penyimpanan 4 $\pm 1^{\circ} \mathrm{C}$ Penambahan Kappaphycus alvarezii, gelatin ikan dan gelatin kaki ayam meningkatkan $(\mathrm{p}<0.05)$ kandungan protein dan abu tetapi menurunkan $(\mathrm{p}<0.05)$ kandungan lemak. Nilai pH bagi sampel T1 dan T2 lebih tinggi berbanding dengan $C$ semasa tempoh penyimpanan. Nilai TBA bagi sampel $T 1$ dan $T 2$ adalah rendah dibandingkan dengan $C$ semasa tempoh penyimpanan. Penambahan Kappaphycus alvarezii, gelatin ikan dan gelatin kaki ayam mengubah warna bagi sampel T1 dan T2 sepanjang tempoh penyimpanan. Penambahan Kappaphycus alvarezii, gelatin ikan dan gelatin kaki ayam mengubah warna sosej ayam sepanjang tempoh penyimpanan. Kajian ini menunjukkan penambahan campuran Kappaphycus alvarezii, gelatin ikan dan gelatin kaki ayam pada tahap optimum menghasilkan sosej ayam yang lebih berkualiti.
\end{abstract}

Kata kunci: Gelatin ikan; gelatin kaki ayam; Kappaphycus alvarezii; sosej ayam; ujian jangka hayat

\section{ABSTRACT}

Kappaphycus alvarezii rich in carrageenan, which is widely used in the food industry as a thickening agent and stabilizer. Fish gelatin and chicken gelatin were used in food products to replace bovine gelatin which has many issues, especially halal and Bovine Spongiform Encephalopathy (BSE). This study was carried out to investigate the effects of the adding Kappaphycus alvarezii, fish gelatin and chicken feet gelatin on quality characteristics of chicken sausages. Two optimum formulation T1 (10\% Kappaphycus alvarezii, 3.81\% fish gelatin, 7.63\% chicken feet gelatin) and T2 (2.57\% Kappaphycus alvarezii, 5\%, fish gelatin, $7.63 \%$ chicken feet gelatin) were analyzed and the quality characteristics were evaluated against control sausage $(C)$. The quality of chicken sausage was based on proximate analysis and shelf life study ( $\mathrm{pH}$, TBA value and colour). The shelf life study was carried out during 3 weeks of chill storage at $4 \pm 1^{\circ} \mathrm{C}$. The addition of Kappaphycus alvarezii, fish gelatin and chicken feet gelatin improved $(\mathrm{p}<0.05)$ ash and protein but reduced $(\mathrm{p}<0.05)$ fat content. Higher $\mathrm{pH}$ values $(\mathrm{p}<0.05)$ were recorded for T1 and T2 in comparison to $C$ during storage time. Lower TBA values $(\mathrm{p}<0.05)$ were recorded for $T 1$ and $T 2$ in comparison to $C$ during storage time. Addition of Kappaphycus alvarezii, fish gelatin and chicken feet gelatin change the colour of sausages throughout the storage periods. This study showed that addition of Kappaphycus alvarezii, fish gelatin and chicken feet gelatin mixture at optimum level produced better quality chicken sausages.

Keywords: Chicken feet gelatin; chicken sausage; fish gelatin; Kappaphycus alvarezii; shelf life study

\section{Pendahuluan}

Dewasa ini, penghasilan dan penggunaan produk daging dan ayam terproses seperti sosej telah meningkat disebabkan faktor perubahan gaya hidup dan tabiat pemakanan. Dalam masa yang sama permintaan pengguna terhadap produk makanan seimbang turut meningkat
(Ordóñez et al. 1997). Babji (2010) menyatakan mutu produk daging terproses perlu dititikberatkan bagi mencapai matlamat kesihatan, pemakanan dan keperluan piawaian kualiti makanan yang diperlukan oleh negara pengimport. Permintaan terhadap produk yang lebih sihat termasuklah produk daging terproses yang rendah lemak, 
kolesterol, garam dan kalori semakin popular pada masa kini.

Hidrokoloid adalah kumpulan pelbagai polimer rantai panjang yang sepenuhnya atau sebahagiannya larut dan mengembang di dalam air. Hidrokoloid mengubah sifat fizikal larutan untuk membentuk gel untuk penebalan, pengemulsian, salutan dan penstabilan. Sebab utama hidrokoloid digunakan dalam industri makanan adalah kerana keupayaannya untuk mengikat air dan meningkatkan kualiti ciri fizikal makanan terutamanya ciri reologi selain mempengaruhi sifat sensori makanan (Laaman 2011).

Rumpai laut kerap digunakan sebagai bahan mentah dalam industri pembuatan dan bahan tambah (agar, karagenan dan alginat) yang digunakan dalam pemprosesan makanan (Venugopal 2011). Seperti yang diketahui, rumpai laut mengandungi kandungan yang tinggi dalam serat pemakanan, protein, kandungan mineral dan vitamin, polifenol, karatenoid serta tokoferol. Walau bagaimanapun, penggunaan rumpai laut spesies Kappaphycus alvarezii dalam produk berasaskan daging kurang diberi perhatian (Wolyna et al. 2017). Pengubahsuaian formulasi produk berasaskan daging bukan sahaja dapat meningkatkan kualiti kesihatan dan nutrisi tetapi juga meningkatkan ciri fizikokimia dalam produk daging.

Gelatin dianggap sebagai diet yang sangat mudah dicerna dan sesuai sebagai pelengkap dalam beberapa jenis diet. Gelatin selalu diaplikasikan dalam makanan, fotografi, kosmetik dan industri farmaseutik. Baru-baru ini, penggunaannya berkembang kepada aplikasi baru seperti koloid penstabil, agen pembuih dan pengemulsi (Schrieber \& Gareis 2007). Penggunaan gelatin ikan adalah sebagai alternatif kepada gelatin yang berasaskan haiwan mamalia yang lain. Ini adalah kerana orang Islam, Yahudi dan Hindu menghadapi masalah dengan gelatin yang dihasilkan daripada lembu dan babi. Oleh itu, penggunaan gelatin ikan adalah alternatif kepada gelatin mamalia yang dapat diterima oleh semua agama sebagai bahan tambah dalam makanan (Gudmundsson 2002). Namun, penggunaan gelatin ikan dalam produk makanan sangat terhad kerana ciri pengelannya (Gomez-Guillen et al. 2002; Liu et al. 2008). Hasil ekstrak gelatin bergantung kepada kandungan rawan. Kandungan rawan yang tinggi boleh menghasilkan gelatin yang lebih banyak (Morrison et al. 1999).

Oleh itu kajian ini adalah untuk menentukan keberkesanan campuran Kappaphycus alvarezii, gelatin ikan dan kaki ayam terhadap ciri fizikokimia dalam meningkatkan kualiti jangka hayat sosej ayam.

\section{BAHAN DAN KAEDAH}

\section{PENYEDIAAN LARUTAN}

Rumpai laut yang digunakan dalam penyelidikan ini diambil dari Semporna, Sabah. Rumpai laut disimpan di dalam peti sejuk pada suhu $4^{\circ} \mathrm{C}$ untuk mengekalkan kesegarannnya. Larutan rumpai laut disediakan dengan mencampurkan 20 g Kappaphycus alvarezii dalam
$100 \mathrm{~mL}$ air dan dipanaskan sehingga larut di dalam air. Penyediaan gelatin kaki ayam adalah berdasarkan Rahman dan Jamalulail (2012) dengan sedikit pengubahsuaian. Kaki ayam dibersihkan; kuku ayam dibuang dan dipotong kecil dalam anggaran 1 hingga $1.5 \mathrm{~cm}$. Kaki ayam yang telah dipotong dimasukkan ke dalam air dan dimasak pada suhu $100^{\circ} \mathrm{C}$ selama $30 \mathrm{~min}$. Masa dihitung apabila air mula mendidih. Nisbah kaki ayam dan air adalah 1:2. Kemudian, air kaki ayam ditapis dan disejukkan sebelum disimpan pada suhu $4^{\circ} \mathrm{C}$. Gelatin ikan diperoleh daripada Yummies Bakeries Sdn Bhd di Bandar Baru Bangi.

\section{PENYEDIAAN SOSEJ AYAM}

Bekalan daging ayam tua diperoleh daripada pasar basah Seksyen 1, Bandar Baru Bangi. Jadual 1 menunjukkan formulasi asas sosej ayam. Daging ayam tua yang telah dikisar dengan pengisar daging (ORIMAS Model TBS 200, Taiwan) ditambahkan dengan garam dan natrium polifosfat untuk mengekstrak protein larut garam bagi menghasilkan emulsi yang baik dan dikisar selama 2 min menggunakan mesin penggaul (DITOSAMA K25 Electrolux, France). Bahan-bahan lain dimasukkan ke dalam campuran dan dikisar selama 2 hingga 3 min. Larutan Kappaphycus alvarezii, gelatin ikan dan gelatin kaki ayam menggantikan peratusan daging ayam tua dicampurkan mengikut setiap perlakuan bersama-sama adunan tadi selama $1 \mathrm{~min}$ sehingga adunan tadi sekata dengan suhu adalah disekitar $10^{\circ} \mathrm{C}$ hingga $15^{\circ} \mathrm{C}$ sepanjang proses pencampuran bagi mengelakkan emulsi rosak dan pengoksidaan dalam daging berlaku. Langkah seterusnya adalah memasukkan adunan ke dalam sarung selulosa sintetik $(\varnothing=2.5 \mathrm{~cm})$ menggunakan alat pengisi. Sosej ayam dimasak dalam oven konveksi (PROTECH Model FAC-350, USA) pada suhu $50^{\circ} \mathrm{C}$ selama $15 \mathrm{~min}, 60^{\circ} \mathrm{C}$ selama $15 \mathrm{~min}, 70^{\circ} \mathrm{C}$ selama 15 min, $80^{\circ} \mathrm{C}$ selama $30 \mathrm{~min}$ dan $85^{\circ} \mathrm{C}$ selama 30 min sehingga mencapai suhu dalaman $74^{\circ} \mathrm{C}$. Sosej dikeluarkan daripada oven dan direndam dalam air ais serta merta. Kemudian, sosej ayam dibungkus mengikut formulasi dan disimpan di dalam peti sejuk beku pada suhu $-18^{\circ} \mathrm{C}$ sehingga analisis dijalankan.

\section{ANALISIS PROKSIMAT}

Kandungan kelembapan, abu, lemak kasar dan protein kasar dalam sampel sosej ayam yang ditambah dengan Kappaphycus alvarezii, gelatin ikan dan gelatin kaki ayam ditentukan dengan menggunakan kaedah AOAC (2005).

\section{UJIAN JANGKA HAYAT PRODUK}

Ujian $p H$ Sebanyak 5 g sampel dihomogenkan dengan $50 \mathrm{~mL}$ air suling dengan menggunakan pengisar selama 2 min. Bacaan $\mathrm{pH}$ diambil dengan menggunakan meter $\mathrm{pH}$ digital (Orion pH Meter 420A, Switzerland) yang telah dikalibrasi dengan pH4 dan pH7 (Menegas et al. 2013).

Ujian Asid Thiobarbiturik (TBA) Nilai TBA telah ditentukan dengan kaedah Buege dan Aust (1978). Nilai 
JADUAL 1. Formulasi sosej ayam

\begin{tabular}{lccc}
\hline \multirow{2}{*}{ Bahan-bahan } & \multicolumn{3}{c}{ Peratusan formulasi sosej } \\
& \multicolumn{3}{c}{$(\%)(w / w)$} \\
\cline { 2 - 4 } & $\mathrm{C}$ & $\mathrm{T} 1$ & $\mathrm{~T} 2$ \\
\hline Daging ayam tua & 55.45 & 34.01 & 40.25 \\
Garam & 0.8 & 0.8 & 0.8 \\
Natrium Tripolifosfat (STPP) & 0.3 & 0.3 & 0.3 \\
Protein Soya Terisolat (ISP) & 4 & 4 & 4 \\
Serbuk Asap & 0.2 & 0.2 & 0.2 \\
Air Ais & 15 & 15 & 15 \\
Lemak ayam & 20 & 20 & 20 \\
Perasa ayam & 0.75 & 0.75 & 0.75 \\
Kanji kentang & 1.5 & 1.5 & 1.5 \\
Serbuk lada hitam & 1 & 1 & 1 \\
Gula & 1 & 1 & 1 \\
Kappaphycus alvarezii & 0 & 10 & 2.57 \\
Gelatin ikan & 0 & 3.81 & 5 \\
Gelatin kaki ayam & 0 & 7.63 & 7.63 \\
\hline Jumlah & 100 & 100 & 100 \\
\hline
\end{tabular}

$(\mathrm{C}=$ sampel kawalan yang tidak ditambah dengan larutan Kappaphycus alvarezii, gelatin ikan dan gelatin kaki ayam)

serapan supernatan ditentukan dengan menggunakan spektrofotometer (Epoch, USA) pada panjang gelombang $532 \mathrm{~nm}$. Nilai TBA dikira berdasarkan formula berikut:

Nilai $\mathrm{TBA}=$ Baca sampel pada $532 \mathrm{~nm} \times 2.77$

Ujian Warna Alat Chromameter (Minolta CR-300, Jepun) digunakan dalam ujian penentuan warna pada permukaan sosej ayam. Setiap formulasi diperlakukan sebanyak tiga kali dan nilai puratanya diambil. Warna direkodkan menggunakan skala CIE-L* $\mathrm{a}^{*} \mathrm{~b}^{*}$. Warna sosej ditunjukkan dalam kadar kecerahan ( $\left.\mathrm{L}^{*}\right)$, kemerahan (a*) dan kekuningan (b*) (García-García \& Totosaus 2008).

\section{ANALISIS PROFIL TEKSTUR}

Ujian dilakukan berdasarkan kepada Bourne (2002) dengan menggunakan penganalisis tekstur (SHIMADZU model AGS-J
500N, Japan). Parameter yang diuji adalah kekerasan, kekenyalan, kekohesifan dan kekunyahan.

\section{ANALISIS STATISTIK}

Semua data yang diperoleh dianalisis menggunakan program SAS 9.1.3 (Statistical Analytical System) untuk menentukan perbezaan signifikan $(p<0.05)$ antara sampel T1, T2 dan C (kawalan) terhadap analisis proksimat dan ujian jangka hayat produk dengan menjalankan ujian ANOVA dan ujian Duncan.

\section{KEPUTUSAN DAN PERBINCANGAN}

\section{ANALISIS PROKSIMAT}

Rajah 1 menunjukkan kesan penambahan pelbagai tahap larutan Kappaphycus alvarezii, gelatin ikan dan gelatin kaki ayam dalam sosej ayam dibandingkan dengan sampel C (kawalan) terhadap analisis proksimat.

Kandungan kelembapan sosej ayam yang mengandungi $10 \%$ Kappaphycus alvarezii, 3.81\% gelatin ikan dan $7.63 \%$ gelatin kaki ayam (T1) menunjukkan perbezaan signifikan yang lebih tinggi $(p<0.05)$ berbanding dengan $2.57 \%$ Kappaphycus alvarezii, 5\% gelatin ikan dan $7.63 \%$ gelatin kaki ayam (T2) tetapi tidak signifikan dengan sampel C. Kandungan gelatin yang tinggi menyebabkan kandungan kelembapan menurun (Suradkar et al. 2013). Kandungan kelembapan merupakan komponen yang penting dalam sosej daging kerbau yang telah dimasak. Ia juga adalah salah satu ciri fisikokimia dalam menentukan atribut sensori seperti kejusian dalam sampel sosej (Khan \& Ahmad 2015).

Keputusan kandungan abu dalam tiga pelakuan sosej dalam Rajah 1 menunjukkan terdapat perbezaan yang signifikan $(p<0.05)$. Peratusan abu bagi sampel T1 (Kappaphycus alvarezii, 3.81\% gelatin ikan, 7.63\% gelatin kaki) lebih tinggi daripada T2 dan C. Kandungan Kappaphycus alvarezii yang kaya dengan sumber mineral semula jadi menyumbang kepada peningkatan kandungan abu dalam sosej ayam. Keputusan ini menyamai hasil

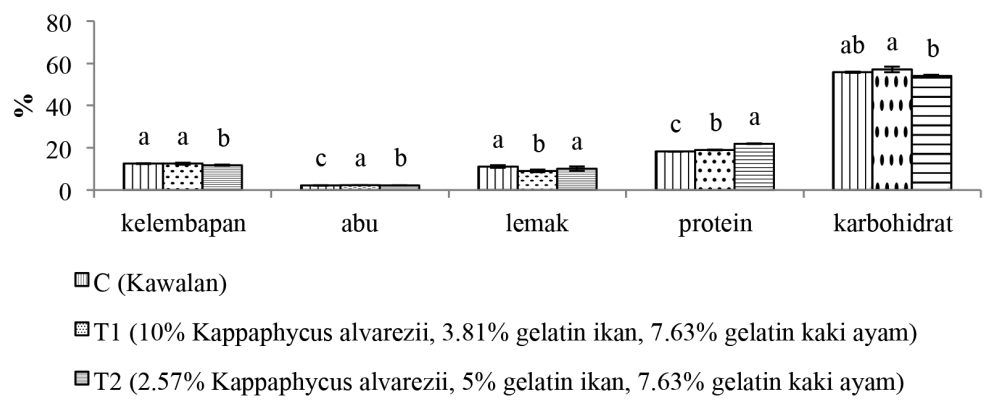

( $\mathrm{C}=$ sampel kawalan yang tidak ditambah dengan larutan Kappaphycus alvarezii, gelatin ikan dan gelatin kaki ayam). Abjad yang berbeza menunjukkan perbezaan yang signifikan bagi keseluruhan histogram $(\mathrm{p}<0.05)$

RAJAH 1. Kesan penambahan larutan Kappaphycus alvarezii, gelatin ikan dan gelatin kaki ayam dalam sosej ayam terhadap analisis proksimat 
kajian yang dijalankan oleh Cofrades et al. (2008) yang mencadangkan penambahan rumpai laut dalam jumlah yang besar meningkatkan kandungan abu dalam sistem emulsi daging.

Penambahan $10 \%$ Kappaphycus alvarezii, $3.81 \%$ gelatin ikan dan $7.63 \%$ gelatin kaki ayam (T1) mengurangkan peratusan lemak dalam sosej secara signifikan $(p<0.05)$ berbanding T2 dan C. Ini mungkin kerana kandungan lemak dalam rumpai laut dan gelatin adalah rendah dengan Kappaphycus alvarezii, gelatin ikan dan gelatin kaki ayam telah menggantikan daging dalam formulasi sosej. Menurut Ahmad et al. (2012), kandungan lemak dalam Kappaphycus alvarezii sangat rendah dan merupakan komponen proksimat minor. Kandungan lemak yang rendah dalam gelatin disyorkan dalam meningkatkan tahap protein dalam makanan (Schrieber \& Gareis 2007). Sampel T2 (2.57\% Kappaphycus alvarezii, 5\% gelatin ikan, $7.63 \%$ gelatin kaki ayam) menunjukkan kandungan protein yang tinggi $(p<0.05)$ berbanding dengan sampel yang lain. Peningkatan tahap protein dalam sosej mungkin disumbangkan oleh kandungan protein dalam gelatin ikan dan gelatin kaki ayam. Menurut Schrieber dan Gareis (2007), gelatin mengandungi kandungan protein yang tinggi dan dapat meningkatkan tahap protein dalam makanan. Kandungan protein dalam jerki ayam separa kering meningkat secara signifikan dengan peningkatan kandungan gelatin kaki ayam (Kim et al. 2012). Namun tiada perbezaan yang signifikan $(p>0.05)$ terhadap protein apabila serbuk Kappaphycus alvarezii ditambah dalam kutlet ikan (Senthil et al. 2005).

\section{UJIAN JANGKA HAYAT PRODUK}

Ujian $p H \quad$ Nilai $\mathrm{pH}$ merupakan ciri fizikokimia yang penting bagi menentukan kualiti dan jangka hayat sosej dengan penambahan pelbagai campuran larutan Kappaphycus alvarezii, gelatin ikan dan gelatin kaki ayam yang berbeza. Perubahan nilai $\mathrm{pH}$ sepanjang tempoh penyimpanan sosej ayam dengan penambahan larutan Kappaphycus alvarezii, gelatin ikan dan gelatin kaki ayam dapat dilihat pada Rajah 2.
Nilai $\mathrm{pH}$ menunjukkan perbezaan yang signifikan $(p<0.05)$ antara T1 dengan sampel $\mathrm{C}$ sepanjang tempoh penyimpanan kecuali pada minggu kedua. Julat nilai $\mathrm{pH}$ bagi sampel C, T1 dan T2 masing-masing adalah 6.21-6.45, 6.04-6.52 dan 6.11-6.43. Ketiga-tiga sampel mempunyai julat nilai $\mathrm{pH}$ antara 6.19 hingga 6.48 dalam keadaan yang segar. Pada awal minggu, sampel T1 mempunyai nilai $\mathrm{pH}$ yang paling tinggi dan menunjukkan perbezaan yang signifikan $(p<0.05)$ terhadap sampel $\mathrm{C}$ tetapi mempunyai nilai $\mathrm{pH}$ yang terendah pada akhir penyimpanan.

Kandungan Kappaphycus alvarezii dalam T1 yang lebih tinggi berbanding T2 memberi kesan yang ketara terhadap nilai $\mathrm{pH}$. Kandungan alkali semula jadi dalam Kappaphycus alvarezii menyumbang kepada peningkatan nilai pH (Das et al. 2015) dalam sampel T1. Menurut Choi et al. (2012), penambahan rumpai laut dalam burger babi meningkatkan nilai $\mathrm{pH}$. Peningkatan kandungan gelatin kaki ayam dalam jerki ayam separa kering menurunkan nilai $\mathrm{pH}$ (Kim et al. 2012). Nilai $\mathrm{pH}$ bagi sampel $\mathrm{T} 2$ mula meningkat pada minggu pertama penyimpanan tetapi menunjukkan penurunan pada minggu kedua sehingga akhir penyimpanan. Ini mungkin disebabkan oleh penguraian protein sepanjang tempoh penyimpanan. Sepanjang tempoh penyimpanan, pengumpulan metabolit yang dihasilkan oleh tindak balas bakteria terhadap protein dan asid amino menyumbang kepada peningkatan nilai $\mathrm{pH}$ (Ch'ng et al. 2014).

Nilai Asid Thiobarbiturik (TBA) Nilai asid thiobarbiturik (TBA) adalah mengukur produk kedua pengoksidaan lipid bagi mengesan pembentukan rasa tengik dalam produk makanan semasa tempoh penyimpanan (Riuz et al. 2001). Rajah 3 menunjukkan nilai TBA dalam sosej ayam dengan penambahan larutan Kappaphycus alvarezii, gelatin ikan dan gelatin kaki ayam sepanjang tempoh penyimpanan.

Semua sampel menunjukkan peningkatan malonaldehid secara signifikan $(p<0.05)$ apabila tempoh penyimpanan meningkat. Peningkatan nilai TBA adalah penunjuk pembentukan ketengikan (Soyer et al. 2010). Nilai asid tiobarbiturik bagi sampel T1 adalah yang paling

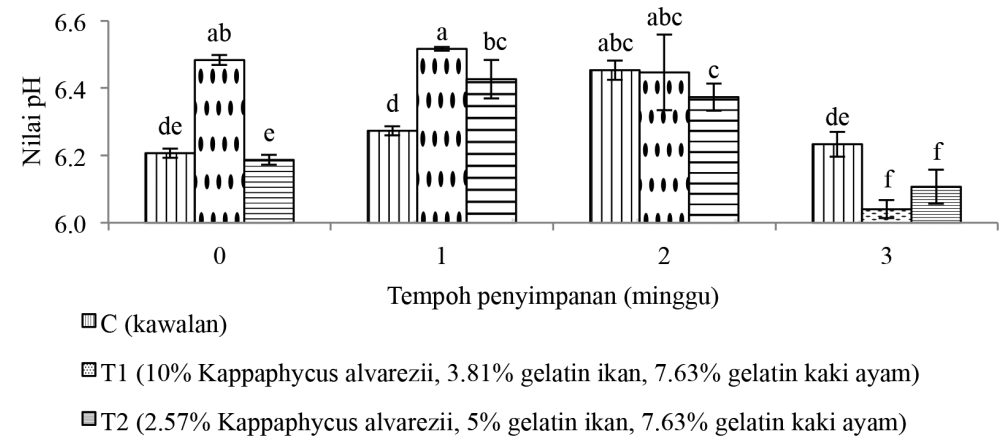

( $\mathrm{C}=$ sampel kawalan yang tidak ditambah dengan larutan Kappaphycus alvarezii, gelatin ikan dan gelatin kaki ayam). Abjad yang berbeza menunjukkan perbezaan yang signifikan bagi keseluruhan histogram $(p<0.05)$

RAJAH 2. Nilai pH dalam sosej ayam dengan penambahan larutan Kappaphycus alvarezii, gelatin ikan dan gelatin kaki ayam sepanjang tempoh penyimpanan 


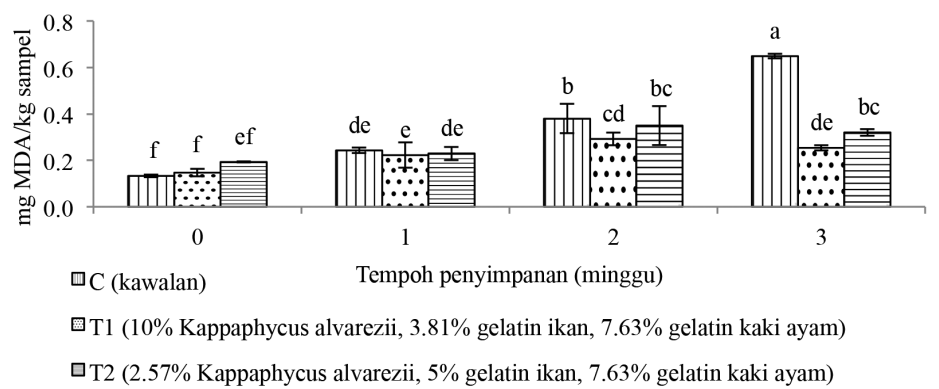

$(\mathrm{C}=$ sampel kawalan yang tidak ditambah dengan larutan Kappaphycus alvarezii, gelatin ikan dan gelatin kaki ayam). Abjad yang berbeza menunjukkan perbezaan yang signifikan bagi keseluruhan histogram $(p<0.05)$

RAJAH 3. Nilai TBA dalam sosej ayam dengan penambahan larutan Kappaphycus alvarezii, gelatin ikan dan gelatin kaki ayam sepanjang tempoh penyimpanan

rendah diikuti dengan $\mathrm{T} 2$ berbanding dengan sampel C selepas 3 minggu tempoh penyimpanan. Sampel T1 dan T2 mempunyai perbezaan yang signifikan $(p<0.05)$ dengan sampel C pada akhir tempoh penyimpanan. Julat nilai TBA bagi sampel $\mathrm{C}$, T1 dan T2 daripada permulaan minggu hingga minggu ketiga masing-masing adalah 0.13-0.656, 0.15-0.25 dan 0.19-0.32 mg MDA/ kg sampel.

Berdasarkan rajah ini, pengoksidaan lemak dalam sampel T1 meningkat dengan lebih perlahan berbanding dengan T2 dan sampel C sepanjang tempoh penyimpanan. Gabungan 10\% Kappaphycus alvarezii, $3.81 \%$ gelatin ikan dan $7.63 \%$ gelatin kaki ayam dalam sampel T1 dapat menurunkan nilai TBA sepanjang tempoh penyimpanan. Menurut Cox dan Abu-Ghannam (2003), nilai TBA burger daging yang mengandungi rumpai laut adalah rendah berbanding dengan sampel yang tidak mengandungi rumpai laut sepanjang tempoh penyimpanan. Aktiviti antioksidan yang tinggi dalam Kappaphycus alvarezii seperti karotenoid, tokoferol dan polifenol secara langsung dan tidak langsung menyumbang kepada perencatan dan perambatan radikal bebas (Abirami \& Kowsalya 2011; Li \& Kim 2011).

Gelatin mempunyai aktiviti oksidan yang tinggi, perencat pengoksidaan lipid dan penghapus radikal bebas (Gómez-Guillén et al. 2011). Walau bagaimanapun, kajian Ch'ng et al. (2014) menyatakan nilai TBA dalam sosej ayam dengan penambahan gelatin adalah lebih tinggi daripada sampel kawalan sepanjang 3 minggu tempoh penyimpanan tetapi nilainya masih berada di bawah nilai kritikal iaitu 0.5 $\mathrm{mg}$ malonaldehid/kg sampel. Dalam kajian ini, formulasi T1 berpotensi sebagai perencat pengoksidaan lipid dan dapat digunakan sebagai pengawet makanan semula jadi bagi mengelakkan kerosakan makanan. Nilai TBA bagi sampel T1 dan T2 adalah di bawah nilai kritikal yang dicadangkan oleh Maiorano et al. (2016) iaitu $0.5 \mathrm{mg}$ malonaldehid/kg sampel yang menunjukkan pembentukan bau dan rasa tengik dalam daging dan produk daging.

Nilai TBA bagi sampel T1 dan T2 tidak berubah $(p>0.05)$ sehingga memasuki minggu ke-2 dalam tempoh penyimpanan berbanding dengan sampel C. Nilai TBA mula meningkat bagi sampel $\mathrm{T} 1$ dan $\mathrm{T} 2$ pada minggu kedua penyimpanan dan hampir tidak berubah selepas beberapa ketika penyimpanan adalah mungkin disebabkan oleh penguraian dan pempolimeran malonaldehid (MDA) (Alina et al. 2012). Formulasi T1 dapat melambatkan pengoksidaan lipid sekunder mungkin disebabkan kandungan rumpai laut yang lebih tinggi berbanding formulasi lain dan merupakan formulasi terbaik kerana kurang teroksida dalam sosej ayam.

Ujian Warna Nilai kecerahan sosej ayam dengan penambahan larutan Kappaphycus alvarezii, gelatin ikan dan gelatin kaki ayam sepanjang tempoh penyimpanan ditunjukkan dalam Jadual 2.

Berdasarkan Jadual 2, penambahan $5.00 \%$ gelatin ikan, 7.63\% gel kaki ayam dan $2.57 \%$ Kappaphycus alvarezii mengurangkan kecerahan sosej sampel secara signifikan $(p<0.05)$ pada awal penyimpanan dan menjadikan nilai $\mathrm{L}^{*}$ bagi $\mathrm{T} 2$ adalah yang paling rendah berbanding $\mathrm{T} 1$ dan sampel C. Nilai kecerahan sampel surimi semakin menurun apabila kandungan gelatin meningkat (Kaewudom \& Benjakul 2011). Kekurangan pigmen heme dalam daging ayam tua menyumbang kepada kecerahan sosej ayam. Kajian Rhee et al. (1999) menyatakan bahawa kandungan heme dalam daging ayam adalah kurang berbanding dengan daging merah yang lain. Kandungan pigmen heme yang kurang disebabkan pengurangan penggunaan daging ayam tua yang telah digantikan dengan $5.00 \%$ gelatin ikan, $7.63 \%$ gel kaki ayam dan $2.57 \%$ Kappaphycus alvarezii telah mengurangkan kecerahan sosej ayam. Namun penambahan $3.81 \%$ gelatin ikan, $7.63 \%$ gel kaki ayam dan $10.00 \%$ Kappaphycus alvarezii meningkatkan kecerahan sampel $\mathrm{T} 1$ berbanding sampel $\mathrm{C}$ pada awal tempoh penyimpanan. Terdapat perbezaan yang signifikan $(p<0.05)$ terhadap kesemua sampel sepanjang tempoh penyimpanan. Tiada perbezaan yang signifikan $(p>0.05)$ dapat dilihat pada tempoh awal dan akhir penyimpanan bagi T1, T2 dan sampel C. Penambahan gelatin ikan dalam sosej ayam tidak menunjukkan kesan yang signifikan terhadap nilai kecerahan sepanjang tempoh penyimpanan (Ch'ng et al. 2014). Kandungan gula yang terdapat dalam sosej berinteraksi dengan kumpulan amino protein semasa pemanasan untuk membentuk produk berwarna perang melalui tindak balas Millard. Menurut Aleson-Carbonell 
et al. (2005), sebatian yang terbentuk semasa tindak balas Maillard pada permukaan burger boleh bertindak sebagai penghomogen untuk koordinat warna tersebut.

Jadual 2 menunjukkan nilai a* bagi permukaan sampel sosej ayam dengan penambahan larutan Kappaphycus alvarezii, gelatin ikan dan gelatin kaki ayam sepanjang tempoh penyimpanan bagi sampel T1, T2 dan C. Terdapat perbezaan yang signifikan $(p<0.05)$ terhadap sampel T1 dan T2 terhadap sampel C sepanjang tempoh penyimpanan. Nilai a* bagi sampel T1 menurun sepanjang tempoh penyimpanan tetapi hampir tidak berubah $(p>0.05)$. Nilai a* bagi sampel T2 menunjukkan trend penurunan sehingga minggu kedua namun meningkat pada akhir penyimpanan secara signifikan $(p<0.05)$. Pengurangan nilai $\mathrm{a}^{*}$ terhadap perlakuan sampel juga mungkin disebabkan oleh kesan penambahan Kappaphycus alvarezii. Rumpai laut mempunyai warna yang sedikit gelap (Venugopal 2011) dan mengandungi pigmen berwarna coklat dan kuning seperti klorofil, phycophine dan xantofil yang mempengaruhi warna sosej. Menurut Senthil et al. (2005), penambahan Kappaphycus alvarezii menurunkan nilai a* dalam kutlet ikan. Penambahan gelatin kaki itik tidak memberi kesan terhadap nilai a* dalam frankfuther ayam (Yeo et al. 2014). Penambahan larutan Kappaphycus alvarezii, gelatin ikan dan gelatin kaki ayam menurunkan nilai a* sampel sosej ayam berbanding sampel C. Penambahan larutan Kappaphycus alvarezii, gelatin ikan dan gelatin kaki ayam telah menggantikan daging ayam tua dalam formulasi sosej. Dalam kajian Lee et al. (2003), peningkatan kandungan daging ayam tua dalam snek bijirin ayam dapat meningkatkan nilai $\mathrm{a}^{*}$.

Jadual 2 menunjukkan nilai $b^{*}$ bagi warna luaran sosej ayam dengan penambahan larutan Kappaphycus alvarezii, gelatin ikan dan gelatin kaki ayam sepanjang tempoh penyimpanan. Penambahan larutan Kappaphycus alvarezii, gelatin ikan dan gelatin kaki ayam dalam sosej ayam tidak memberi kesan yang siginifikan $(p>0.05)$ terhadap nilai $b^{*}$ berbanding dengan sampel $C$. Penambahan rumpai laut (Porphyra umbilicalis) dalam sistem gel daging tidak memberi kesan terhadap nilai $b^{*}$ (Cofrades et al. 2008). Nilai $b^{*}$ hampir tidak berubah $(p>0.05)$ sepanjang tempoh penyimpanan bagi kesemua sampel. Nilai b* bagi sampel sosej ayam yang ditambah dengan gelatin ikan (Ch'ng et al. 2014) dan rumpai laut (López-López et al. 2009) tidak berubah sepanjang tempoh penyimpanan.

\section{ANALISIS PROFIL TEKSTUR}

Jadual 3 menunjukkan nilai analisis profil tekstur dalam sosej ayam dengan penambahan larutan Kappaphycus alvarezii, gelatin ikan dan gelatin kaki ayam sepanjang tempoh penyimpanan.

Penambahan larutan Kappaphycus alvarezii, gelatin ikan dan gelatin kaki ayam memberikan kesan yang signifikan $(p<0.05)$ terhadap kekerasan, kekenyalan, kekohesifan dan kekunyahan sampel. Kekerasan sampel T1 meningkat pada minggu ke-2 secara signifikan dan tidak menunjukkan perubahan yang ketara $(p>0.05)$ sehingga akhir tempoh penyimpanan. Kekerasan sampel T2 mula menurun secara signifikan $(p<0.05)$ sehingga minggu ke-3 namun mula meningkat pada akhir tempoh penyimpanan. Nilai kekerasan semakin menurun mungkin kerana dalam tempoh penyimpanan, penghidratan berlaku terhadap sampel. Peningkatan nilai kekerasan disebabkan oleh kehilangan air daripada produk frankfurter rendah lemak semasa penyimpanan sejuk (Andrés et al . 2006). Sampel T1 dan T2 kurang kenyal berbanding sampel C secara signifikan $(p<0.05)$ mungkin disebabkan penambahan rumpai laut dan gelatin dalam sosej ayam. Penambahan rumpai laut (LópezLópez et al. 2009) dan gelatin (Kaewudom et al. 2012) dalam produk daging mengurangkan nilai kekenyalan. Pengurangan nilai kekohesifan mungkin disebabkan oleh pengurangan peratusan daging ayam tua yang telah digantikan dengan larutan Kappaphycus alvarezii, gelatin ikan dan gelatin kaki ayam. Selain itu, kehadiran kandungan air yang tinggi dalam larutan gelatin kaki ayam

JADUAL 2. Nilai L*, a* dan b* sosej ayam dengan penambahan larutan Kappaphycus alvarezii, gelatin ikan dan gelatin kaki ayam sepanjang tempoh penyimpanan

\begin{tabular}{|c|c|c|c|c|}
\hline Minggu & Sampel & $\mathrm{L}^{*}$ & $a^{*}$ & $b^{*}$ \\
\hline \multirow{3}{*}{0} & $\mathrm{C}$ & ${ }^{\mathrm{abc}} 51.61 \pm 0.37$ & ${ }^{\mathrm{a}} 6.35 \pm 0.02$ & ${ }^{\mathrm{ab}} 11.85 \pm 0.417$ \\
\hline & $\mathrm{T} 1$ & a52.87 \pm 0.49 & $\mathrm{~d} 4.85 \pm 0.02$ & ${ }^{\mathrm{a}} 12.31 \pm 0.519$ \\
\hline & $\mathrm{T} 2$ & ef $49.26 \pm 0.84$ & bc5.72 \pm 0.14 & ${ }^{\mathrm{b}} 11.11 \pm 0.41$ \\
\hline \multirow{3}{*}{1} & $\mathrm{C}$ & ab $52.24 \pm 0.10$ & ${ }^{b} 5.77 \pm 0.06$ & ab $11.68 \pm 0.15$ \\
\hline & $\mathrm{T} 1$ & cde $50.50 \pm 0.18$ & de $4.69 \pm 0.06$ & ab $11.59 \pm 0.11$ \\
\hline & $\mathrm{T} 2$ & ${ }^{\mathrm{bcd}} \mathrm{b} 51.19 \pm 0.99$ & $\mathrm{~d} 4.82 \pm 0.17$ & ${ }^{\mathrm{b}} 11.21 \pm 0.37$ \\
\hline \multirow{3}{*}{2} & $\mathrm{C}$ & abc51.89 \pm 0.69 & ${ }^{c} 5.55 \pm 0.22$ & b $11.21 \pm 0.13$ \\
\hline & $\mathrm{T} 1$ & bcde $50.75 \pm 1.08$ & ef $4.53 \pm 0.03$ & b $11.19 \pm 0.72$ \\
\hline & $\mathrm{T} 2$ & ${ }^{\mathrm{f}} 48.25 \pm 0.61$ & ef $4.50 \pm 0.01$ & b $11.15 \pm 0.55$ \\
\hline \multirow{3}{*}{3} & $\mathrm{C}$ & bcd $51.08 \pm 1.28$ & ${ }^{\mathrm{b}} 5.90 \pm 0.08$ & ab $11.66 \pm 0.21$ \\
\hline & $\mathrm{T} 1$ & abc $51.83 \pm 0.62$ & ${ }^{\mathrm{f}} 4.49 \pm 0.08$ & ${ }^{\mathrm{a}} 12.02 \pm 0.40$ \\
\hline & $\mathrm{T} 2$ & $\operatorname{def} 49.66 \pm 1.53$ & b5 $5.77 \pm 0.16$ & $9.97 \pm 0.33$ \\
\hline
\end{tabular}

( $\mathrm{C}=$ sampel kawalan yang tidak ditambah dengan larutan Kappaphycus alvarezii, gelatin ikan dan gelatin kaki ayam). Abjad yang berbeza menunjukkan perbezaan yang signifikan bagi keseluruhan jadual $(p<0.05)$ 
JADUAL 3. Nilai analisis profil tekstur sosej ayam dengan penambahan larutan Kappaphycus alvarezii, gelatin ikan dan gelatin kaki ayam sepanjang tempoh penyimpanan

\begin{tabular}{|c|c|c|c|c|c|}
\hline Minggu & Sampel & $\begin{array}{c}\text { Kekerasan } \\
(\mathrm{N})\end{array}$ & $\begin{array}{c}\text { Kekenyalan } \\
(\mathrm{mm})\end{array}$ & Kekohesifan & $\begin{array}{l}\text { Kekunyahan } \\
\text { (N mm) }\end{array}$ \\
\hline \multirow{3}{*}{0} & $\mathrm{C}$ & $\mathrm{a} 74.35 \pm 3.81$ & a $1.05 \pm 0.04$ & ${ }^{\mathrm{abc}} 0.33 \pm 0.02$ & ${ }^{\mathrm{a}} 18.29 \pm 0.70$ \\
\hline & $\mathrm{T} 1$ & fg $31.16 \pm 2.76$ & b $0.97 \pm 0.02$ & ${ }^{\mathrm{e}} 0.23 \pm 0.02$ & ${ }^{\text {cdef } 11.99 \pm 3.23 ~}$ \\
\hline & $\mathrm{T} 2$ & fg $32.01 \pm 1.12$ & ${ }^{c} 0.87 \pm 0.01$ & ${ }^{a} 0.34 \pm 0.02$ & ${ }^{\mathrm{abc}} 14.09 \pm 1.93$ \\
\hline \multirow{3}{*}{1} & $\mathrm{C}$ & bc $66.51 \pm 4.18$ & ab $0.98 \pm 0.01$ & ${ }^{\mathrm{abc}} 0.32 \pm 0.02$ & ${ }^{\mathrm{a}} 18.47 \pm 2.76$ \\
\hline & $\mathrm{T} 1$ & de $39.39 \pm 3.84$ & ${ }^{c} 0.85 \pm 0.02$ & ${ }^{\mathrm{de}} 0.24 \pm 0.02$ & def $8.70 \pm 1.23$ \\
\hline & $\mathrm{T} 2$ & g29.31 40.98 & ${ }^{c} 0.82 \pm 0.04$ & ${ }^{\mathrm{abc}} 0.32 \pm 0.03$ & bcd $13.16 \pm 4.29$ \\
\hline \multirow{3}{*}{2} & $\mathrm{C}$ & 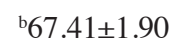 & ab $0.99 \pm 0.04$ & ${ }^{\mathrm{abc}} 0.30 \pm 0.02$ & ${ }^{\mathrm{ab}} 17.52 \pm 1.61$ \\
\hline & $\mathrm{T} 1$ & ef $37.42 \pm 0.41$ & ${ }^{\mathrm{ab}} 1.00 \pm 0.03$ & ${ }^{\mathrm{e}} 0.20 \pm 0.02$ & ef $8.36 \pm 2.49$ \\
\hline & $\mathrm{T} 2$ & $\mathrm{~g} 30.55 \pm 1.00$ & ${ }^{c} 0.84 \pm 0.01$ & ${ }^{\mathrm{abc}} 0.31 \pm 0.03$ & ${ }^{\mathrm{bc}} 13.38 \pm 3.51$ \\
\hline \multirow{3}{*}{3} & $\mathrm{C}$ & ${ }^{\mathrm{c}} 60.47 \pm 6.14$ & ab $1.04 \pm 0.04$ & ${ }^{\mathrm{cd}} 0.28 \pm 0.03$ & ${ }^{\mathrm{ab}} 17.28 \pm 2.95$ \\
\hline & $\mathrm{T} 1$ & efg $35.90 \pm 7.22$ & ${ }^{\mathrm{ab}} 0.97 \pm 0.10$ & ${ }^{\mathrm{bc}} 0.29 \pm 0.29$ & f $7.68 \pm 0.23$ \\
\hline & $\mathrm{T} 2$ & $\mathrm{~d} 43.87 \pm 2.32$ & ${ }^{c} 0.86 \pm 0.07$ & ${ }^{\mathrm{ab}} 0.33 \pm 0.05$ & ${ }^{\text {cde }} 12.36 \pm 1.44$ \\
\hline
\end{tabular}

$(\mathrm{C}=$ sampel kawalan yang tidak ditambah dengan larutan Kappaphycus alvarezii, gelatin ikan dan gelatin kaki ayam). Abjad yang berbeza menunjukkan perbezaan yang signifikan bagi keseluruhan jadual $(p<0.05)$

menyumbang kepada pengurangan nilai kekohesifan. Menurut Pereira et al. (2011), pengurangan kandungan protein dan peningkatan kandungan air mengurangkan nilai kekohesifan menyebabkan keupayaan pengemulsian dalam formulasi juga berkurang. Sampel T1 mempunyai nilai kekunyahan yang terendah berbanding dengan sampel T2 dan C. Kappaphycus alvarezii, gelatin ikan dan gelatin kaki ayam mengurangkan nilai kekunyahan sampel sosej ayam. Nilai kekunyahan bagi setiap sampel menunjukkan penurunan namun nilainya hampir tidak berubah $(p>0.05)$ sepanjang tempoh penyimpanan. Penambahan rumpai laut dalam frankfurter ayam memberi kesan yang kecil terhadap kekunyahan sepanjang tempoh penyimpanan (López-López et al. 2009).

\section{KESIMPULAN}

Penambahan Kappaphycus alvarezii, gelatin ikan dan gelatin kaki ayam telah meningkatkan kandungan protein dan abu selain mengurangkan kandungan lemak secara signifikan $(p<0.05)$ berbanding sampel kawalan. Penambahan Kappaphycus alvarezii, gelatin ikan dan gelatin kaki ayam dalam sosej ayam telah menurunkan nilai TBAdan meningkatkan nilai $\mathrm{pH}$ secara signifikan $(p<0.05)$ sepanjang tempoh penyimpanan berbanding sampel kawalan. Warna dan nilai tekstur profil analisis sosej ayam berubah dengan penambahan Kappaphycus alvarezii, gelatin ikan dan gelatin kaki ayam. Sampel T1 yang telah ditambah dengan 10\% Kappaphycus alvarezii, 3.81\% gelatin ikan, $7.63 \%$ gelatin kaki ayam dapat memanjangkan jangka hayat sosej ayam berbanding dengan sampel $\mathrm{C}$ (kawalan) dan T2. Kappaphycus alvarezii, gelatin ikan dan gelatin kaki ayam boleh dijadikan bahan tambah dalam produk daging bagi menggantikan daging tanpa menjejaskan kebanyakan ciri fizikokimia selain dapat menjimatkan kos bahan. Penambahan Kappaphycus alvarezii, gelatin ikan dan gelatin kaki ayam dengan kombinasi campuran optimum dapat menghasilkan kualiti sosej ayam yang lebih baik.

\section{PENGHARGAAN}

Penulis berterima kasih kepada Kementerian Pengajian Tinggi, Malaysia atas pembiayaan kajian ini di bawah geran penyelidikan FRGS/2/2013/ST04/UKM/01/1.

\section{RUJUKAN}

Abirami, R.G. \& Kowsalya, S. 2011. Nutrient and nutraceutical potentials of seaweed biomass Ulva lactuca and Kappaphycus alvarezii. Journal of Agricultural Science and Technology 5(1): 109-115.

Ahmad, F., Sulaiman, M.R., Saimon, W., Chye, F.Y.\& Matanjun, P. 2012. Proximate compositions and total phenolic contents of selected edible seaweed from Semporna, Sabah, Malaysia. Borneo Science 31: 85-96.

Aleson-Carbonell, L., Fernández-López, J., Pérez-Alvarez, J.A . \& Kuri, V. 2005. Characteristics of beef burger as influenced by various types of lemon albedo. Innovative Food Science \& Emerging Technologies 6(2): 247-255.

Alina, A.R., Siti Mashitoh, A., Babji, A.S., Maznah, I., Syamsul, K.M.W.\& Muhyiddin, Y. 2012. Oxidative stability of smoked chicken sausage substituted with red palm mid fraction during chilled storage. World Applied Sciences Journal (Towards the Traceability of Halal and Thoyyiban Application) 17: 62-66.

Andrés, S.C., Garcıa, M.E., Zaritzky, N.E. \& Califano, A.N. 2006. Storage stability of low-fat chicken sausages. Journal of food Engineering 72(4): 311-319.

Babji, A.S. 2010. Sains Daging Terproses. Ed. ke-2. Bangi: Penerbit Universiti Kebangsaan Malaysia.

Bourne, M.C. 2002. Food Texture and Viscosity: Concept and Measurement. Ed. Ke-2. Waltham, MA: Academic Press.

Buege, J.A. \& Aust, S.D. 1978. Microsomal lipid peroxidation. Methods in Enzymology 52: 302-304.

Ch'ng, S.E., Ng, M.D., Pindi, W., Kang, O.L., Abdullah, A. \& Babji A.S. 2014. Chicken sausages formulated with gelatin from different sources: A comparison of sensory acceptability 
and storage stability. World Applied Sciences Journal 31(12): 2062-2067.

Choi, Y.S., Choi, J.H., Han, D.J., Kim, H.Y., Kim, H. W., Lee, M.A., Chung, H.J. \& Kim, C.J. 2012. Effects of Laminaria japonica on the physico-chemical and sensory characteristics of reduced-fat pork patties. Meat science 91(1): 1-7.

Cofrades, S., Lopez-Lopez, I., Solas, M.T., Bravo L. \& JimenezColmenero, F. 2008. Influence of different types and proportions of added edible seaweeds on characteristics of low-salt gel/emulsion meat systems. Meat Science 79(4): 767-776.

Cox, S. \& Abu-Ghannam, N. 2013. Enhancement of the phytochemical and fibre content of beef-patties with Himanthalia elongata seaweed. International Journal of Food Science and Technology 48(11): 2239-2249.

Das, S.K., Prabhakaran, P., Tanwar, V.K. \& Biswas, S. 2015. Effect of some plant starches and carrageenan as fat substitutes in chicken patties. Journal of Animal Science 93(7): 3704-3712.

García-García, E. \& Totosaus, A. 2008. Low-fat sodium-reduced sausages: Effect of the interaction between locust bean gum, potato starch and $\mathrm{k}$-carrageenan by a mixture design approach. Meat Science 78(4): 406-413

Gómez-Guillen, M.C., Giménez, B., López-Caballero, M.E. \& Montero, M.P. 2011. Functional and bioactive properties of collagen and gelatin from alternative sources: A review. Food Hydrocolloids 25(8): 1813-1827.

Gomez-Guillen, M.C., Turnay, J., Fernandez-Diaz, M.D., Ulmo, N.,Lizarbe, M.A. \& Montero, P. 2002. Structural and physical properties of gelatin extracted from different marine species: A comparative study. Food Hydrocolloids 16(1): 25-34.

Gudmundsson, M. 2002. Rheological properties of fish gelatins. Journal of Food Science 67(6): 2172-2176.

Kaewudom, P. \& Benjakul, S. 2011. Properties of surimi gel as influenced by the addition of fish gelatin and oxidized tannic acid. The 12 $2^{\text {th }}$ ASEAN Food Conference 2011: 481-484.

Khan, I. \& Ahmad, S. 2015. Studies on physicochemical properties of cooked buffalo meat sausage as influenced by incorporation of carrot powder during refrigerated storage. Journal of Food Processing and Technology 6(4): 1-5.

Kim, H.Y., Kim, K.J., Lee, J.W., Kim, G.W. \& Kim, C.J. 2012. Effects of chicken feet gelatin and wheat fiber levels on quality properties of semi-dried chicken jerky. Korean Journal for Food Science of Animal Resources 32(6): 732739.

Laaman, T.R. 2011. Hydrocolloids in Food Processing. New York: John Wiley \& Sons.

Lee, S.O., Min, J.S., Kim, I.S. \& Lee, M. 2003. Physical evaluation of popped cereal snacks with spent hen meat. Meat Science 64(4): 383-390.

Li, Y.X. \& Kim, S.K. 2011. Utilization of seaweed derived ingredients as potential antioxidants and functional ingredients in the food industry: An overview. Food Science and Biotechnology 20(6): 1461-1466.

Liu, H., Li, D. \& Guo, S. 2008. Rheological properties of channel catfish (Ictalurus punctaus) gelatine from fish skins preserved by different methods. LWT Food Science and Technology 41(8): 414-419.

López-López, I., Cofrades, S. \& Jiménez-Colmenero, F. 2009. Low-fat frankfurters enriched with n-3 PUFA and edible seaweed: Effects of olive oil and chilled storage on physicochemical, sensory and microbial characteristics. Meat Science 83(1): 148-154.
Maiorano, G., Angwech, H., Di Memmo, D., Wilkanowska, A., Mucci, R., Abiuso, C. \& Tavaniello, S. 2016. Effects of intramuscular vitamin $\mathrm{E}$ multiple injections on quality, oxidative stability and consumer acceptability of meat from Laticauda lambs fed under natural rearing conditions. Small Ruminant Research 139: 52-59.

Menegas, L.Z., Pimentel, T.C., Garcia, S. \& Prudencio, S.H. 2013. Dry-fermented chicken sausage produced with inulin and corn oil: Physicochemical, microbiological, and textural characteristics and acceptability during storage. Meat Science 93(3): 501-506

Morrison, N.A., Clark, R.C., Chen, Y.L., Talashek, T. \& Sworn, G. 1999. Gelatin alternatives for the food industry: Physical chemistry and industrial application of gellan gum. Progress in Colloid and Polymer Science 114: 127-131.

Ordóñez, J.A., Hierro, E.M., Bruna, J.M. \& Hoz, L.D.L. 1999. Changes in the components of dry-fermented sausages during ripening. Critical Reviews in Food Science and Nutrition 39(4): 329-367.

Pereira, A.G.T., Ramos, E.M., Teixeira, J.T., Cardoso, G.P., Ramos, A.D.L.S. \& Fontes, P.R. 2011. Effects of the addition of mechanically deboned poultry meat and collagen fibers on quality characteristics of frankfurter-type sausages. Meat Science 89(4): 519-525.

Rahman, N. \& Jamalulail, S. 2012. Extraction, physicochemical characterizations and sensory quality of chicken feet gelatin. Borneo Science 30: 1-13.

Rhee, K.S., Cho, S.H. \& Pradahn, A.M. 1999. Composition, storage stability and sensory properties of expanded extrudates from blends of corn starch and goat meat, lamb, mutton, spent fowl meat, or beef. Meat Science 52(2): 135141.

Riuz, A., Ayora-Canada, M.J. \& Lendl, B. 2001. A rapid method for peroxide value determination in edible oils based on flow analysis with Fourier transform infrared spectroscopic detection. Analyst 126(2): 242-246.

Schrieber, R. \& Gareis, H. 2007. Gelatine Handbook: Theory and Industrial Practice. Weinheim: WILEY-VCH Verlag $\mathrm{GmbH} \& \mathrm{Co}$

Senthil, M.A., Mamatha, B.S. \& Mahadevaswamy, M. 2005. Effect of using seaweed (Eucheuma) powder on the quality of fish cutlet. International Journal of Food Sciences and Nutrition 56(5): 327-335.

Soyer, A., Özalp, B., Dalmış, Ü. \& Bilgin, V. 2010. Effects of freezing temperature and duration of frozen storage on lipid and protein oxidation in chicken meat. Food Chemistry 120(4): 1025-1030

Suradkar, U.S., Bumla, N.A., Maria, A., Sofi, H.A. \& Wani, S.A. 2013. Comparative quality of chicken nuggets prepared from broiler, spent hen and combination meats. International Journal of Food Nutrition and Safety 3(3): 119-126.

Venugopal, V.2011. Marine Polysaccharides Food Applications. Boca Raton: CRC Press Taylor \& Francis Group.

Wolyna,P., Hin, W.M., Munsu, E. \& Ab Wahab, N. 2017. Effects of addition of Kappaphycus alvarezii on physicochemical properties and lipid oxidation of mechanically deboned chicken meat (MDCM) sausages. British Food Journal 119(10): 2229-2239.

Yeo, E.J., Kim, H.W., Hwang, K.E., Song, D.H., Kim, Y.J., Ham, Y.K., He, F.Y., Park, J.H. \& Kim, C.J. 2014. Effect of duck feet gelatin on physicochemical, textural, and sensory properties of low-fat frankfurters. Korean Journal for Food Science of Animal Resources 34(4): 415-422. 
School of Chemical Science and Food Technology Faculty of Science and Technology

Universiti Kebangsaan Malaysia

43600 UKM Bangi, Selangor Darul Ehsan

Malaysia
*Pengarang untuk surat-menyurat; email: salma_my@ukm. edu.my

Diserahkan: 11 Oktober 2017

Diterima: 25 Januari 2018 